Egyptian Journal of Aquatic Biology \& Fisheries

Zoology Department, Faculty of Science,

Ain Shams University, Cairo, Egypt.

ISSN $1110-6131$

Vol. 24(7): 553 - 573 (2020)

www.ejabf.journals.ekb.eg

\title{
Impact of the size of commercial bivalves on bioaccumulation and depuration of heavy metals
}

\author{
Mahmoud Sami*, Nesreen K. Ibrahim, Deyaaedin A. Mohammad \\ Department of Marine Science, Faculty of Science, Suez Canal University, Egypt. \\ *Corresponding Author: Mahmoud_Sami@science.suez.edu.eg
}

\section{ARTICLE INFO \\ Article History: \\ Received: Sept. 27, 2020 \\ Accepted: Nov. 8, 2020 \\ Online: Nov. 9, 2020}

Keywords:

heavy metals;

bioaccumulation;

depuration;

clam size;

bivalve

\begin{abstract}
The edible clams from Lake Timsah are exposed to different industrial wastes which may reflect the reason for the high concentration of heavy metals in studied species. The current study aims to evaluate the effect of size classes on the elimination of heavy metals $(\mathrm{Cu}, \mathrm{Fe}, \mathrm{Pb}, \mathrm{Co}, \mathrm{Ni}$, and $\mathrm{Zn})$ in some commercial bivalves Ruditapes decussatus, Venerupis pullastra and Paphia undulata. Negative correlations were found between the sizes of studied species for all heavy metals (except $\mathrm{Cu}$ which showed a positive correlation with size in $V$. pullastra). The concentrations of all heavy metals $(\mathrm{Cu}, \mathrm{Fe}, \mathrm{Pb}, \mathrm{Co}$, and $\mathrm{Zn})$ in the studied species were higher than those in water and sediment. The highest depuration rate for all studied species was recorded in small clam classes.
\end{abstract}

\section{INTRODUCTION}

The coastal areas and estuaries are the most exposed areas to chemical pollution. (Almeida and Soares, 2012). In many countries, increasing of the industrialization and agricultural activities contribute to an increasing of discharge of chemical pollutants into the ecosystem, which lead to increase in metals levels in the natural waters that causing damage of fresh and marine habitats (Muhammad et al., 2011; El Nemr, 2012). Trace metals exist naturally in the earth's crust. Some of them are essential for biological systems, since they participate in numerous enzymatic processes (Pellerin and Amiard, 2009). On the other hand, trace metals such as cadmium, lead and mercury are generally toxic for organisms, even at low concentrations (Stankovic and Jovic, 2012). Their bioaccumulation in tissues lead to intoxication, decreased fertility, cellular and tissue damage, cell death, dysfunction of a variety of organs and induce cancer in humans (Benavides et al., 2005; Nordberg, 2010).

Bivalve molluscs can take up contaminants from sediments, suspended particulate materials, water column and also food sources (Laffon $\boldsymbol{e t}$ al., 2006). They have been widely used for many years as bioindicator organisms in monitoring of chemical 
pollutants and biomonitoring in aquatic ecosystems. This is particularly due to their sedentary nature or immobility, filter-feeding activity, low metabolism, contact with sediments, wide distribution in all environments, ability to bioaccumulate pollutants and high tolerance to chemical exposure due to a remarkably active immune system (Waykar and Deshmukh, 2012; Zuykov et al., 2013).

The bioaccumulation rate of metals in bivalves depends on biotic factors (e.g. species, age, sex, soft-body weight, gametogenesis and physiological status) and abiotic factors (e.g. availability of contaminants in the environment, filtration rate, temperature, salinity, $\mathrm{pH}$, chemical species and interaction with other elements) (Fernandez- Tajes et al., 2011). Venerid clams represent the most commercially important and successful group of bivalves in Suez Canal particularly in Lake Timsah and the Bitter Lakes (Mohammed et al., 1992). In Egypt, these clams are greatly appreciated by seafood consumers. Moreover, the clam industry has suffered a decline in sales in the local market as a result of heightened publicity being given to clam-related illnesses. Heavy metals, among other contaminants, are present in high concentrations in industrial effluents discharged into Lake Timsah (Ibrahim and Abu El- Regal, 2014; Marwa and El-HaK, 2017).

There are two types of depuration:1) Facility based depuration, 2) Relay depuration. The first type depends on moving the contaminated shellfish to land based depuration facility where the shellfish is extensively cleansed with clean water. However, this process is expensive and causing stress to the shellfish. The second type relies on natural cleaning process that occurs when the contaminated shellfish transferred to approved or cleaned water (Chalek, 2013).

Depuration rates of shellfish impacted by many factors including size, siphoning activity, physiological conditions (Richards, 1988; Jones et al., 1991), type and amount of contamination, water quality parameters such as temperature and salinity (Chalek, 2013), shellfish to water ratio, flow rate, oxygenation, species and duration (jones et al., 1991; Barile et al., 2009; Cozzi et al., 2009; Lee et al., 2010; Anacleto, 2014).

Most studies concerning depuration exposed bivalves to pollutants in the laboratory and then transferred them to clean waters under laboratory or field conditions (Wahi $\boldsymbol{e t}$ al., 2009). A few studies used clams containing naturally high concentrations of heavy metals and followed their depuration at a relatively clean field (El-Shenawy, 2004). No information was reported on the impact of different parameters (clam size, temperature and etc....) on depuration and survival of the commercial clams. The current study aims to evaluate the effect of clam size on elimination of heavy metals $(\mathrm{Cu}, \mathrm{Fe}, \mathrm{Pb}, \mathrm{Co}, \mathrm{Ni}$ and $\mathrm{Zn}$ ) in some commercial bivalves Ruditapes decussatus, Venerupis pullastra and Paphia undulata. 


\section{MATERIALS AND METHODS}

\section{Sample collection and set up}

The experiment was performed in the Mariculture laboratory, at the Department of Marine Science, Suez Canal University, Ismailia. The clam species $R$. decussatus, $V$. pullastra and $P$. undulata were collected from their location in Lake Timsah in February 2019. In the laboratory, samples of clams were first cleaned to eliminate any debris and then splashed by distilled water. Their shell lengths were measured by a digital Vernier caliper with an accuracy of $0.01 \mathrm{~mm}$. The edible part of the meat was carefully removed by shelling the samples with a plastic knife. The soft tissues were placed only in plastic bags and frozen until it was examined. Samples of water and sediment were collected from the same site to determine the initial level of heavy metals. Water samples were collected from a precise depth corresponding to the bivalve settlements. Sediment samples were collected and dried to a constant weight at $80^{\circ} \mathrm{C}$ and then stored in polyethylene bags until analysis.

\section{Depuration experiments}

The depuration experiments were commenced within $4 \mathrm{~h}$ of shellfish collection. The water that used in all experiments is synthetic with salinity $25 \%$ and the water changed in all tanks twice a day to avoid absorption of depurated contaminants. Before the start of depuration experiments, the heavy metals $(\mathrm{Cu}, \mathrm{Fe}, \mathrm{Pb}, \mathrm{Co}, \mathrm{Ni}$ and $\mathrm{Zn})$ in all sizes classes of clams were measured ( 0 day or before depuration). Survival of clams throughout the treatments was monitored daily. Shells that were found open but did not close when touched were considered dead and therefore removed. Number of dead clams was recorded and computed into mortality rates.

Depuration experiment: Thirty plastic tanks $(3 \mathrm{~L})$ were used. The experiment was implemented at constant temperature $\left(15 \pm 1^{\circ} \mathrm{c}\right)$. The experiments were carried out in three replicates for each clam size with 3 days depuration time. $R$. decussatus divided into four size classes (15-20, 20-25, 25-30 and 30-35 mm) while $V$. pullastra and $P$. undulata divided into three size classes (15-20, 20-25 and 25-30) and (20-25, 25-30 and 30-35 $\mathrm{mm}$ ), respectively.

\section{Metal Analysis}

The results for metal concentration are expressed as milligrams per liter (ppm), micrograms per gram of dry weight, and micrograms per gram of dry weight in water, clam tissue, and sediment, respectively.

\section{Determination of heavy metals concentration in bottom sediment}

In order to detect heavy metals contamination in sediment samples, an exact weight of the dry sediment sample $(0.5 \mathrm{~g})$ was fully digested in Teflon vessels using mixture of concentrated acids (analar nitric acid $\left(\mathrm{HNO}_{3}\right)$ and $\left.\mathrm{HCLO}_{4}\right)$ for about 2 hours (triplicate digestion were made for each sample). The final solution was diluted to $25 \mathrm{ml}$ with distilled de- ionized water (Oregioni and Astone, 1984). Their metal content was measured by AAS described by Usero et al. (2005). 


\section{Determination of heavy metals concentration in water}

Water samples were obtained and filtered through a $0.45 \mu \mathrm{m}$ membrane in one liter of white polyethylene bottles. The concentration of the following heavy metals: $\mathrm{Cu}, \mathrm{Fe}, \mathrm{Pb}$, $\mathrm{Co}, \mathrm{Ni}$ and $\mathrm{Zn}$ were determined by digesting 100 of each water sample at $100{ }^{\circ} \mathrm{C}$ in $5 \mathrm{ml}$ analar grade nitric acid $\left(\mathrm{HNO}_{3}\right)$ for 5 hours. The digested samples were allowed to stand overnight at room temperature before the heavy metal residual was analyzed in accordance with Standard method 3110 (APHA, 1992).

\section{Determination of heavy metals concentration in soft parts of studied species}

The soft tissues were dried 12 hours before examination at $70{ }^{\circ} \mathrm{C}$. The analytical procedure used to measure the metals $\mathrm{Cu}, \mathrm{Fe}, \mathrm{Pb}, \mathrm{Co}, \mathrm{Ni}$ and $\mathrm{Zn}$ was based on UNEP/FAO/IAEA (1982) with modification as follows: sub-sample (dried) tissue ( $0.5 \mathrm{~g})$ was heated with $10 \mathrm{ml}$ of concentrated nitric acid $\left(70\right.$ to $\left.90^{\circ} \mathrm{C}\right)$ till all tissue had been digested. The temperature was then gradually increased to $135{ }^{\circ} \mathrm{C}$ and drops of $\mathrm{H}_{2} \mathrm{O}_{2}$ added for further oxidation. After cooling, solutions were diluted to $50 \mathrm{ml}$ with double distilled water and filtered with $1.6 \mu \mathrm{m}$ fiberglass filter paper (GF/A). Samples were then stored at room temperature in $50 \mathrm{ml}$ volumetric flask until they were analyzed. Analyses were carried out with flame Atomic Absorption Spectrophotometer (AAS) (Perkin Elmer 2380, Faculty of Science, Ismailia, Egypt) with electrode discharge lamps (EDL) and hollow cathode lamp (HCL).

\section{Metal pollution index}

To compare the total content of metals of the three different clam species, Metal Pollution Index (MPI) was used, obtained with the equation (Usero et al., 1997): where,

$$
\begin{gathered}
\text { MPI = (Cf1, } x \text { Cf2, ... Cfn })^{1 / n}[1] \\
\text { Cfi }=\text { concentration factor for the metal } i \text { in the sample. } \\
n=\text { number of metals. }
\end{gathered}
$$

\section{Bioaccumulation factor (BAF) and bioaccumulation sediment factor (BASF)}

The distribution behavior of heavy metals between water and biota can be expressed as a bioaccumulation factor (BAF) (Chevereuil et al., 1996). To evaluate the efficiency of metal bioaccumulation in bivalves, the bioaccumulation sediment factor (BASF) was calculated as a ratio of the average bivalve metal to the average sediment concentration at a given time (Zhao et al. 2012).

$$
\mathrm{BAF}=\frac{C X}{C W}
$$

Where CX: mean metal concentrationin clams,

$\mathrm{CW}$ : mean concentration metal in water

$$
\mathrm{BASF}=\frac{C X}{C S}
$$

Where CX: mean metal concentration in clams, CS: mean metal concentration in sediment 


\section{Metal depuration rate $\left(\boldsymbol{\mu g} / \mathrm{g} \mathrm{day}^{-1}\right)$}

The rate of metal depuration was calculated according to the following formula (Yap et al., 2003):

Metal depuration rate $=\frac{\text { Metal level before depuration }- \text { Metal levelafter depuration }}{\text { Days of depuration }}$

\section{Metal depuration percentage or reduction rate $(\%)$}

Reduction rate $(\%)=\frac{\text { Metal level before depuration }- \text { Metal levelafter depuration }}{\text { Metal level before depuration }} \times 100$ [5]

\section{Statistical analysis}

Data were expressed as mean \pm standard deviation (SD). Statistical analysis was performed using SPSS (Version 22). One-way Analysis of variance (ANOVA) used to test the significant differences between concentration of heavy metals in different studied species, water, and sediment and between the zero and third day of depuration. If significant differences were present, Tukey's HSD test was employed to check for differences between means. Relationships between size classes and metal concentration and reduction rates were performed through the correlation matrix. Significance levels for all analysis were set at $\mathrm{p}<0.05$.

\section{RESULTS}

\section{Initial concentration of heavy metals in water, sediments and organisms:}

The concentrations of heavy metals in water, sediment and soft body of studied species are presented in tables 1 and 2 . The concentration of all heavy metals $(\mathrm{Cu}, \mathrm{Fe}, \mathrm{Pb}$, $\mathrm{Co}$ and $\mathrm{Zn}$ ) in the studied species was higher than their concentration in water and sediment. However, nickel reading showed high values in sediment compared to water and organisms.

Fe was considered the most dominant metal in water, sediment and the studied species while $\mathrm{Cu}$ was the lowest concentration. The descending order of heavy metals was: $\mathrm{Fe}>\mathrm{Co}>\mathrm{Ni}>\mathrm{Pb}>\mathrm{Zn}>\mathrm{Cu}$; $\mathrm{Fe}>\mathrm{Zn}>\mathrm{Ni}>\mathrm{Co}>\mathrm{Pb}>\mathrm{Cu}$; $\mathrm{Fe}>\mathrm{Zn}>\mathrm{Pb}>\mathrm{Co}>\mathrm{Ni}>\mathrm{Cu}$; $\mathrm{Fe}>\mathrm{Zn}>\mathrm{Ni}>\mathrm{Pb}>\mathrm{Co}>\mathrm{Cu} ; \mathrm{Fe}>\mathrm{Zn}>\mathrm{Pb}>\mathrm{Co}>\mathrm{Ni}>\mathrm{Cu}$ for water, sediment, $R$. decussatus, $P$. undulata and $V$. pullastra, respectively.

Generally, there was significant difference in the concentration of heavy metals between the three studied species $(\mathrm{p}<0.01)$. The highest concentration of $\mathrm{Cu}$ and $\mathrm{Fe}$ recorded in $R$. decussatus while $\mathrm{Pb}$ and Co recorded highest values in $V$. pullastra. On other hand $\mathrm{Ni}$ and $\mathrm{Zn}$ recorded greatest values in P. undulata. R. decusstaus had the highest metal pollution index (MPI) while the lowest MPI was recorded in $V$. pullastra (Table 3).

The values of bioaccumulation factor (BAF) are summarized in Table 1. The order of BAF according to highest concentration or descending was: $\mathrm{Zn}>\mathrm{Pb}>\mathrm{Cu}>\mathrm{Fe}>\mathrm{Ni}>\mathrm{Co}$; $\mathrm{Zn}>\mathrm{Pb}>\mathrm{Fe}>\mathrm{Ni}>\mathrm{Cu}>\mathrm{Co} ; \mathrm{Zn}>\mathrm{Pb}>\mathrm{Cu}>\mathrm{Fe}>\mathrm{Ni}>\mathrm{Co}$ for $R$. decussatus, $P$. undulataand $V$. pullastra, respectively. Table 2 shows the values of bioaccumulation sediment factor 
(BSAF). BASF arranged in the following order: $\mathrm{Fe}>\mathrm{Zn}>\mathrm{Pb}>\mathrm{Co}>\mathrm{Ni}>\mathrm{Cu}$; $\mathrm{Fe}>\mathrm{Zn}>$ $\mathrm{Ni}>\mathrm{Pb}>\mathrm{Co}>\mathrm{Cu} ; \mathrm{Pb}>\mathrm{Cu}>\mathrm{Fe}>\mathrm{Co}>\mathrm{Zn}>\mathrm{Ni}$ for $R$. decussatus, $P$. undulata and $V$. pullastra, respectively.

Table 1: Mean concentration of heavy metals in water, studied species and its bioaccumulation factor (BAF).

\begin{tabular}{|c|c|c|c|c|c|c|c|}
\hline \multirow[b]{2}{*}{ Mretal } & \multirow[b]{2}{*}{$\begin{array}{c}\text { Mean of } \\
\text { metal conc. } \\
\text { in water } \\
(m g / L)\end{array}$} & \multicolumn{2}{|c|}{ R- decussatus } & \multicolumn{2}{|c|}{ V-pullastra } & \multicolumn{2}{|c|}{ P-veredulata } \\
\hline & & $\begin{array}{c}\text { Mean of } \\
\text { metal conc. } \\
\text { in animals } \\
(\mu g / g)\end{array}$ & BAF & $\begin{array}{c}\text { Mean of } \\
\text { metal conc } \\
\text { in animals } \\
(\mu g / g)\end{array}$ & BAF & $\begin{array}{c}\text { Mean of } \\
\text { metal conc. } \\
\text { in animals } \\
(\mu g / g)\end{array}$ & BAF \\
\hline $\mathrm{Cu}$ & 0.21 & 11.86 & 56.49 & 9.39 & 44.73 & 5.22 & 24.86 \\
\hline Fe & 5.7 & 309.63 & 54.32 & 115.01 & 20.18 & 217.37 & 38.14 \\
\hline $\mathbf{P b}$ & 0.55 & 42.49 & 77.25 & 5o.15 & 91.18 & 32.44 & 58.99 \\
\hline $\mathrm{CO}$ & 1.65 & 20.21 & 12.25 & 23.69 & 14.36 & 18.04 & 10.94 \\
\hline Ni & 0.94 & 19.83 & 21.10 & 16.34 & 17.38 & 32.56 & 34.64 \\
\hline$Z n$ & 0.41 & 105.73 & 257.88 & 52.78 & 128.74 & 112.17 & $273 \leq 8$ \\
\hline
\end{tabular}

Table2: Mean concentration of heavy metals in sediment, studied species and its bioaccumulation sediment factor (BASF).

\begin{tabular}{|c|c|c|c|c|c|c|c|}
\hline \multirow[b]{2}{*}{ Metal } & \multirow[b]{2}{*}{$\begin{array}{l}\text { Mean of metal } \\
\text { conc. in } \\
\text { sediment (Hg/g } \\
\text { dry weight) }\end{array}$} & \multicolumn{2}{|c|}{ R. decussatus } & \multicolumn{2}{|c|}{ V-pullastra } & \multicolumn{2}{|c|}{ P. verndulata } \\
\hline & & $\begin{array}{c}\text { Mean of } \\
\text { metal conc } \\
\text { in animals } \\
(\mu g / g)\end{array}$ & BASF & $\begin{array}{c}\text { Mean of } \\
\text { metal conc } \\
\text { in animals } \\
(\mu g / g)\end{array}$ & BASF & $\begin{array}{c}\text { Mean of } \\
\text { metal conc } \\
\text { in animals } \\
(\mu g / g)\end{array}$ & BASF \\
\hline $\mathrm{Cu}$ & 2.34 & 11.86 & 5.07 & 9.39 & 4.01 & 5.22 & 2.23 \\
\hline $\mathrm{Fe}$ & 50.4 & 309.63 & 6.14 & 115.01 & 2.28 & 217.37 & 4.31 \\
\hline $\mathbf{P b}$ & 5.4 & 42.49 & 7.87 & 50.15 & 9.29 & 32.44 & 6.01 \\
\hline Co & 12.33 & 20.21 & 1.64 & 23.69 & 1.92 & 18.04 & 1.46 \\
\hline Ni & 20.8 & 19.83 & 0.95 & 16.34 & 0.79 & 32.56 & 1.57 \\
\hline $\mathrm{Zn}$ & 32.4 & 105.73 & 3.26 & 52.78 & 1.63 & 112.17 & 3.46 \\
\hline
\end{tabular}

Table 3: Metal pollution index (MPI) for total heavy metals in different size classes of the studied species.

\begin{tabular}{|c|c|c|c|c|c|c|c|c|c|c|}
\hline \multirow{2}{*}{ Sp. } & \multicolumn{4}{|c|}{$R$. decussatus } & \multicolumn{3}{c|}{ V. pullastra } & \multicolumn{3}{c|}{ P. undulata } \\
\cline { 2 - 11 } & $\begin{array}{c}15-20 \\
\mathrm{~mm}\end{array}$ & $\begin{array}{c}20-25 \\
\mathrm{~mm}\end{array}$ & $\begin{array}{c}25-30 \\
\mathrm{~mm}\end{array}$ & $\begin{array}{c}30-35 \\
\mathrm{~mm}\end{array}$ & $\begin{array}{c}15-20 \\
\mathrm{~mm}\end{array}$ & $\begin{array}{c}20-25 \\
\mathrm{~mm}\end{array}$ & $\begin{array}{c}25-30 \\
\mathrm{~mm}\end{array}$ & $\begin{array}{c}20-25 \\
\mathrm{~mm}\end{array}$ & $\begin{array}{c}25-30 \\
\mathrm{~mm}\end{array}$ & $\begin{array}{c}30-35 \\
\mathrm{~mm}\end{array}$ \\
\hline MPI & $\mathbf{4 . 0 0}$ & $\mathbf{4 . 0 6}$ & $\mathbf{2 . 6 0}$ & $\mathbf{1 . 8 7}$ & $\mathbf{2 . 4 5}$ & $\mathbf{2 . 2 3}$ & 1.99 & $\mathbf{3 . 3 9}$ & $\mathbf{2 . 9 7}$ & $\mathbf{1 . 7 4}$ \\
\hline Mean & \multicolumn{4}{|c|}{3.13} & \multicolumn{3}{c|}{$\mathbf{2 . 2 2}$} & \multicolumn{3}{c|}{$\mathbf{2 . 7}$} \\
\hline
\end{tabular}

\section{Initial concentration of heavy metals in different size clams:}

The initial concentrations of heavy metals (with different size classes) for studied species are illustrated in Figs. 1-3. The size classes 20-25mm, 20-25 mm and 15-20 mm had the highest MPI for $R$. decussatus, $P$. undulata and $V$. pullastra, respectively, while the lowest values of MPI recorded in $30-35 \mathrm{~mm}$ size class for $R$. decussatus, and $P$. undulate and 25-30 $\mathrm{mm}$ for $V$. pullastra (Table 3 ).

Table 4 shows Pearson correlation between metal concentrations and different molluscan size classes. Negative correlations were found between the size of $R$. decussatus, $P$. undulataand $V$. pullastra for all heavy metals except $\mathrm{Cu}$ and $\mathrm{Fe}$ which showed positive correlation with length for $V$. pullastra only. In $R$. decussatus, there was significant correlation in length or size classes with $\mathrm{Cu}, \mathrm{Fe}, \mathrm{Pb}$ and $\mathrm{Zn} . P$. undulata had significant correlation in all metals except $\mathrm{Co}$ and $\mathrm{Zn}$, while $V$. pullastra had significant correlation with $\mathrm{Fe}, \mathrm{Cu}$ and $\mathrm{Zn}$ (Table 4). 
Table 4: Pearson correlation coefficient (r) between metal concentrations and clam size

\begin{tabular}{|c|c|c|}
\hline Species & metals & $\mathrm{r}$ \\
\hline \multirow{6}{*}{ R. decussatus } & $\mathrm{Cu}$ & $-0.706^{*}$ \\
\hline & $\mathrm{Fe}$ & $-0.624^{*}$ \\
\hline & $\mathrm{Pb}$ & $-0.893^{* \pi}$ \\
\hline & $\mathrm{Co}$ & -0.526 \\
\hline & $\mathrm{Ni}$ & -0.397 \\
\hline & $\mathrm{Zn}$ & $-0.842^{* \pi}$ \\
\hline \multirow{6}{*}{ P. undulata } & $\mathrm{Cu}$ & $-0.813^{* \pi}$ \\
\hline & $\mathrm{Fe}$ & $-0.949^{\star \star *}$ \\
\hline & $\mathrm{Pb}$ & $-0.775^{*}$ \\
\hline & $\mathrm{Co}$ & -0.339 \\
\hline & $\mathrm{Ni}$ & $-0.991^{\star \star}$ \\
\hline & $\mathrm{Zn}$ & -0.386 \\
\hline \multirow{6}{*}{$V$. pullastra } & $\mathrm{Cu}$ & $0.733^{*}$ \\
\hline & $\mathrm{Fe}$ & $0.794^{*}$ \\
\hline & $\mathrm{Pb}$ & -0.638 \\
\hline & $\mathrm{Co}$ & -0.437 \\
\hline & $\mathrm{Ni}$ & -0.259 \\
\hline & $\mathrm{Zn}$ & $-0.771^{*}$ \\
\hline
\end{tabular}

Significant level: $*=\mathrm{p}<0.05 ; * *=\mathrm{p}<0.01$

$\mathrm{Cu}$

$\mathrm{Fe}$

$\mathrm{Pb}$
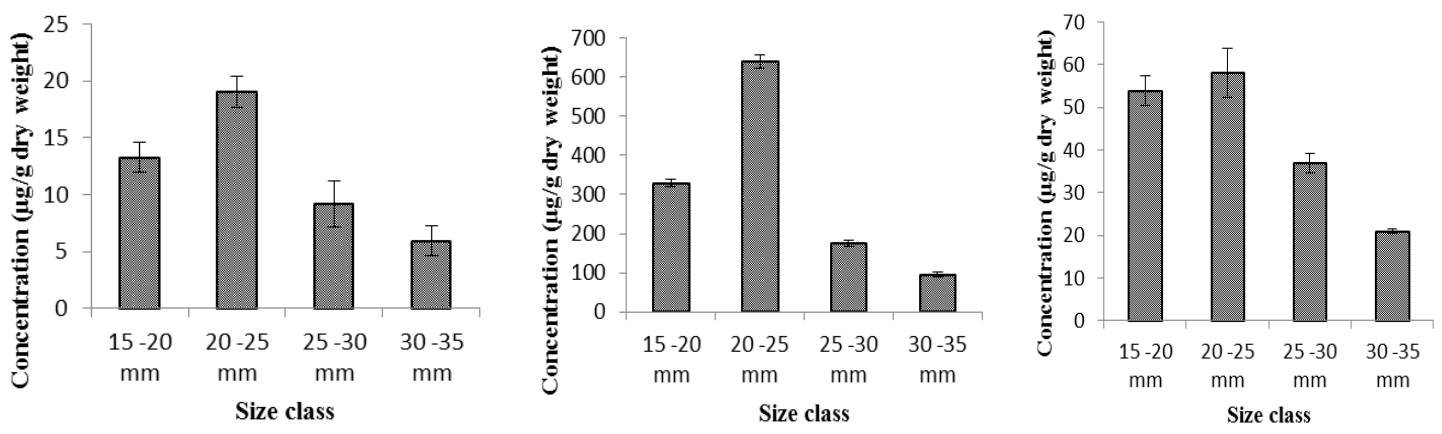

Co
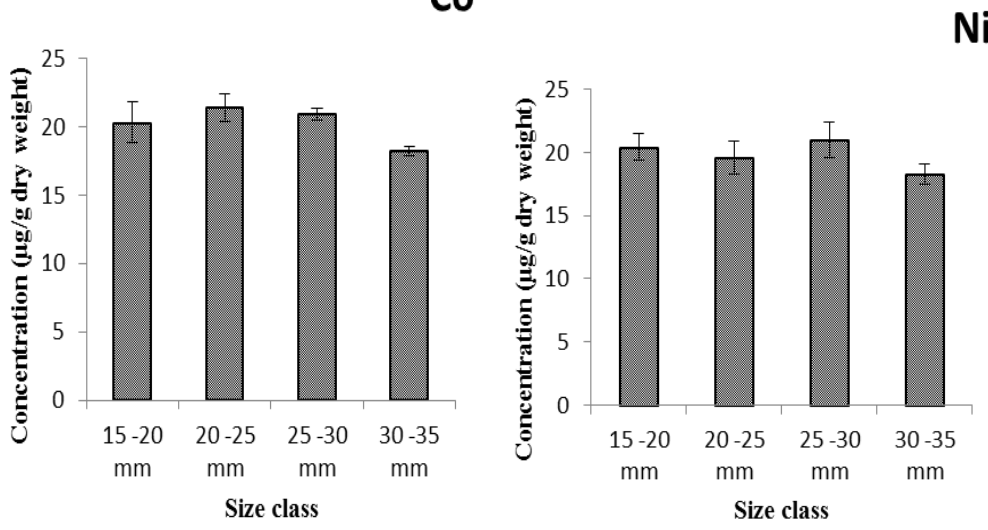

$\mathrm{Zn}$

Fig.1: Concentration of heavy metals in the different size classes of Ruditapes decussatus 
$\mathrm{Cu}$

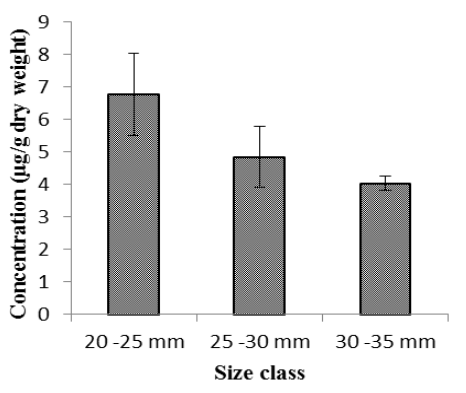

Co

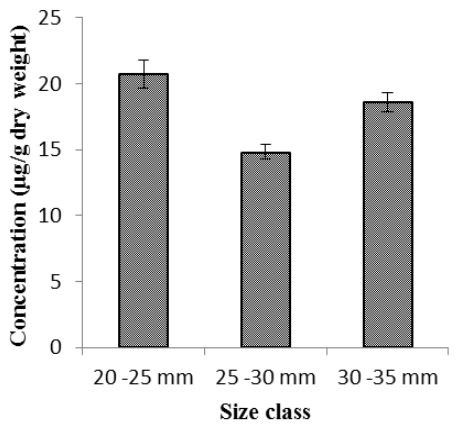

$\mathrm{Fe}$

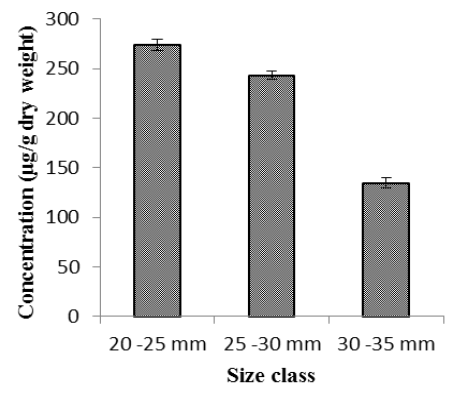

$\mathrm{Ni}$

$\mathrm{Zn}$

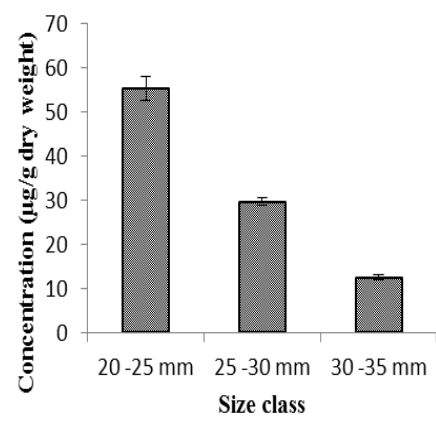

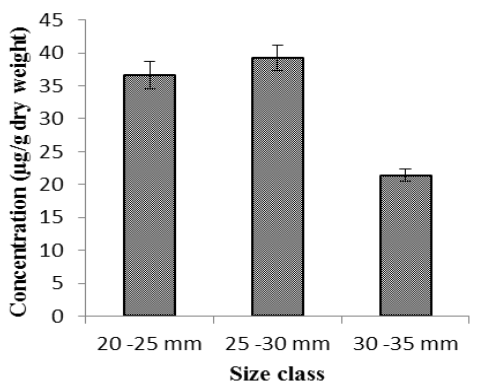

$\mathrm{Pb}$

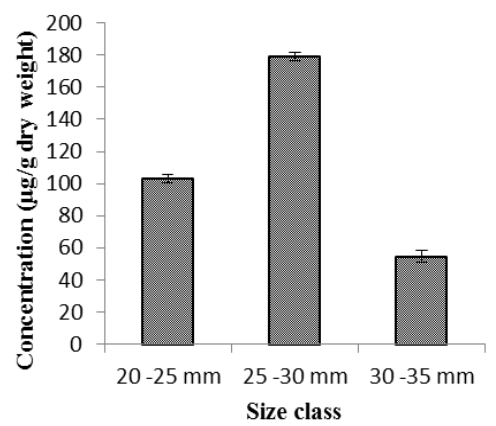

Fig. 2: Concentration of heavy metals in the different size classes of Paphia undulata

\section{$\mathrm{Cu}$}

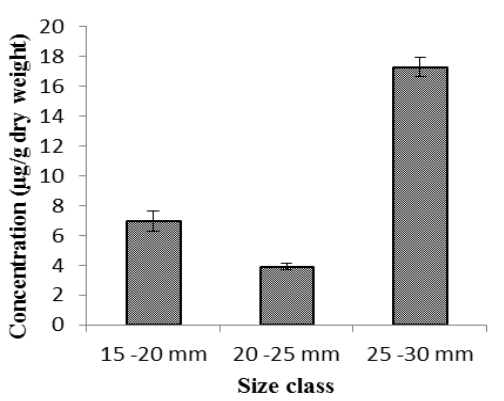

$\mathrm{Fe}$

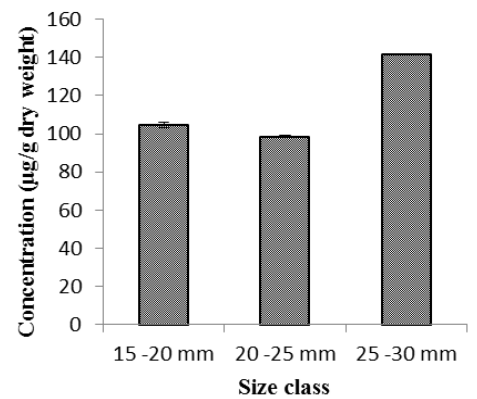

$\mathrm{Pb}$

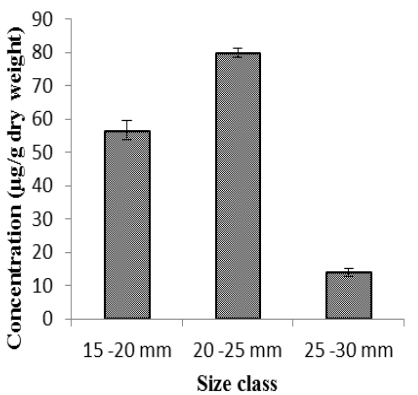

Co
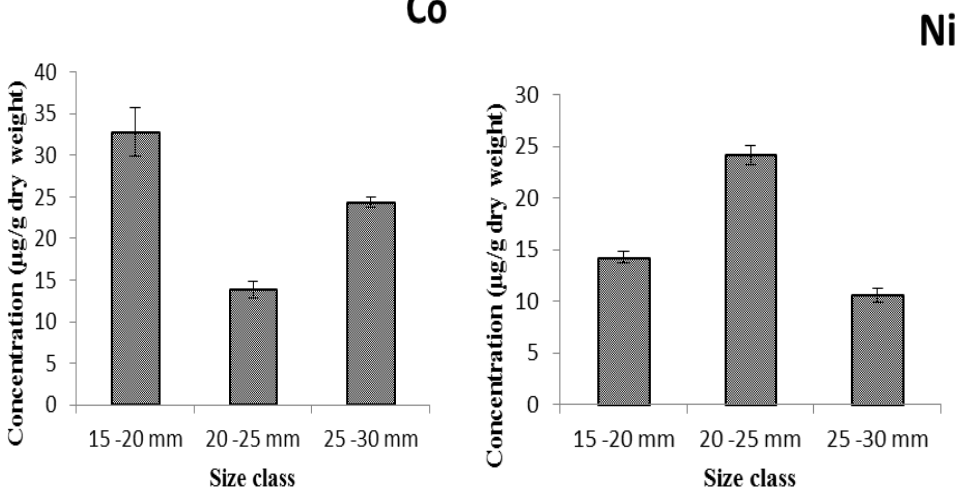

$\mathrm{Ni}$

Fig.3: Concentration of heavy metals in the different size classes of Venerupis pullastra. 


\section{Depuration Experiment}

The concentration of heavy metals before and after depuration with different size classes for studied species are presented or showed in Figs. 4- 6. The concentration of all heavy metals for studied species after 3 days of depuration were significantly decreased compared with initial concentration $(\mathrm{p}<0.05)$. There was significant difference between the depuration rate of all heavy metals for all studied species $(\mathrm{P}<0.01)$. The highest depuration rate or the faster reduction for concentration of $\mathrm{Cu}, \mathrm{Fe}, \mathrm{Pb}, \mathrm{Co}, \mathrm{Ni}$ and $\mathrm{Zn}$ rate were recorded at size classes $20-25 \mathrm{~mm}, 20-25 \mathrm{~mm}, 20-25 \mathrm{~mm}, 25-30 \mathrm{~mm}, 25-30 \mathrm{~mm}$ and $15-20 \mathrm{~mm}$, respectively, for $R$. decussatus while the lowest values for all heavy metals were recorded at size class $30-35 \mathrm{~mm}$ for $R$. decussatus (Tables5 and 6). The highest depuration rate for $\mathrm{Cu}, \mathrm{Pb}$, and $\mathrm{Zn}$ were recorded at sizes classes $25-30 \mathrm{~mm}$ for $P$. undulata while the highest depuration rate for $\mathrm{Fe}, \mathrm{Co}$ and $\mathrm{Ni}$ were recorded at size class 20- $25 \mathrm{~mm}$ for $P$. undulata. The lowest values for all heavy metals were recorded at size class 30-35 mm for $P$. undulata. The highest depuration rate for $\mathrm{Fe}, \mathrm{Pb}, \mathrm{Ni}$ and $\mathrm{Zn}$ rate were recorded at sizes classes $20-25 \mathrm{~mm}$ for $V$. pullastra. The highest depuration rate or the faster reduction for $\mathrm{Cu}$ and $\mathrm{Co}$ were recorded at size class $25-30 \mathrm{~mm}$ and $15-20 \mathrm{~mm}$, respectively, for $V$. pullastra. The lowest values for all heavy metals were recorded at size class 25-30 $\mathrm{mm}$ for $V$. pullastra except $\mathrm{Cu}$ and $\mathrm{Co}$ (20-25mm size class) (Tables 5 and 6).

Table 7 showed the Pearson correlation between metal depuration rate and different bivalve size classes. Negative correlations were found between the sizes of studied species for all heavy metals (except $\mathrm{Cu}$ which showed positive correlation with size in $V$. pullastra). The smallest animals had high depuration rate compared with the large animals. In $R$. decussatus, there was significant correlation in length or size classes with depuration rates of $\mathrm{Cu}, \mathrm{Fe}, \mathrm{Pb}$ and $\mathrm{Zn}$.P. undulata had significant correlation in all metals (except $\mathrm{Cu}$ and $\mathrm{Zn}$ ). However, V. pullastra had no significant correlation with all metals (except $\mathrm{Cu}$ and $\mathrm{Co}$ ) (Table 7).

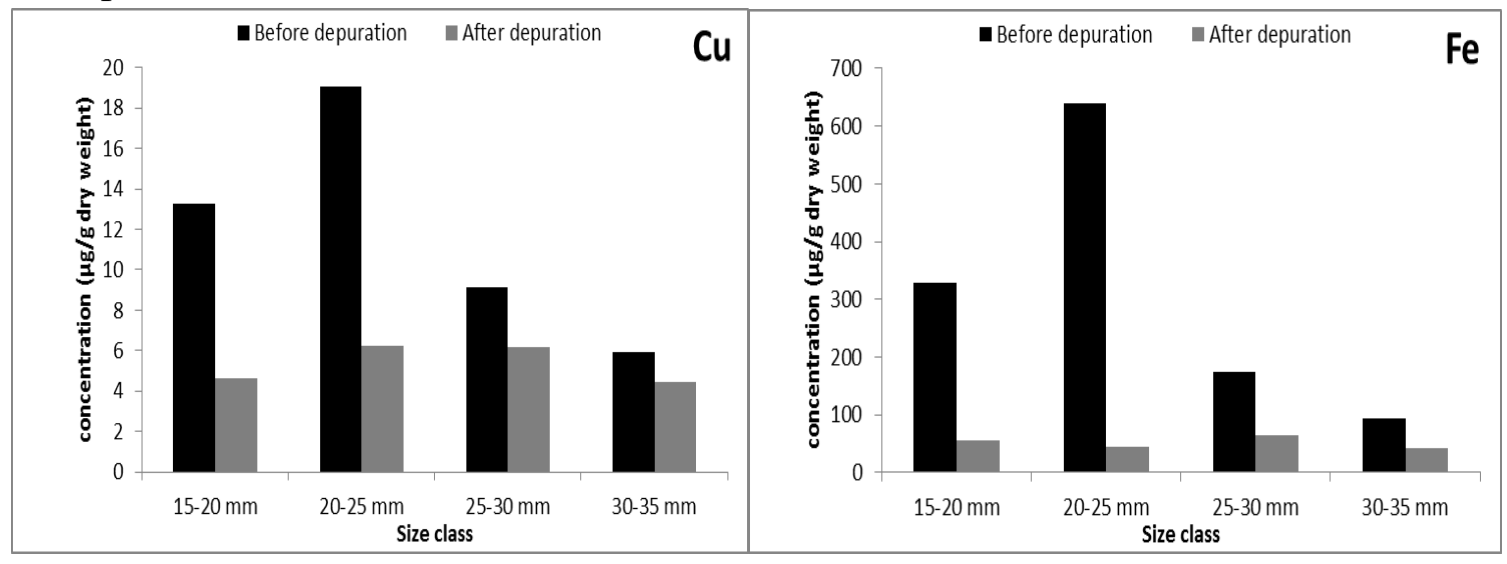




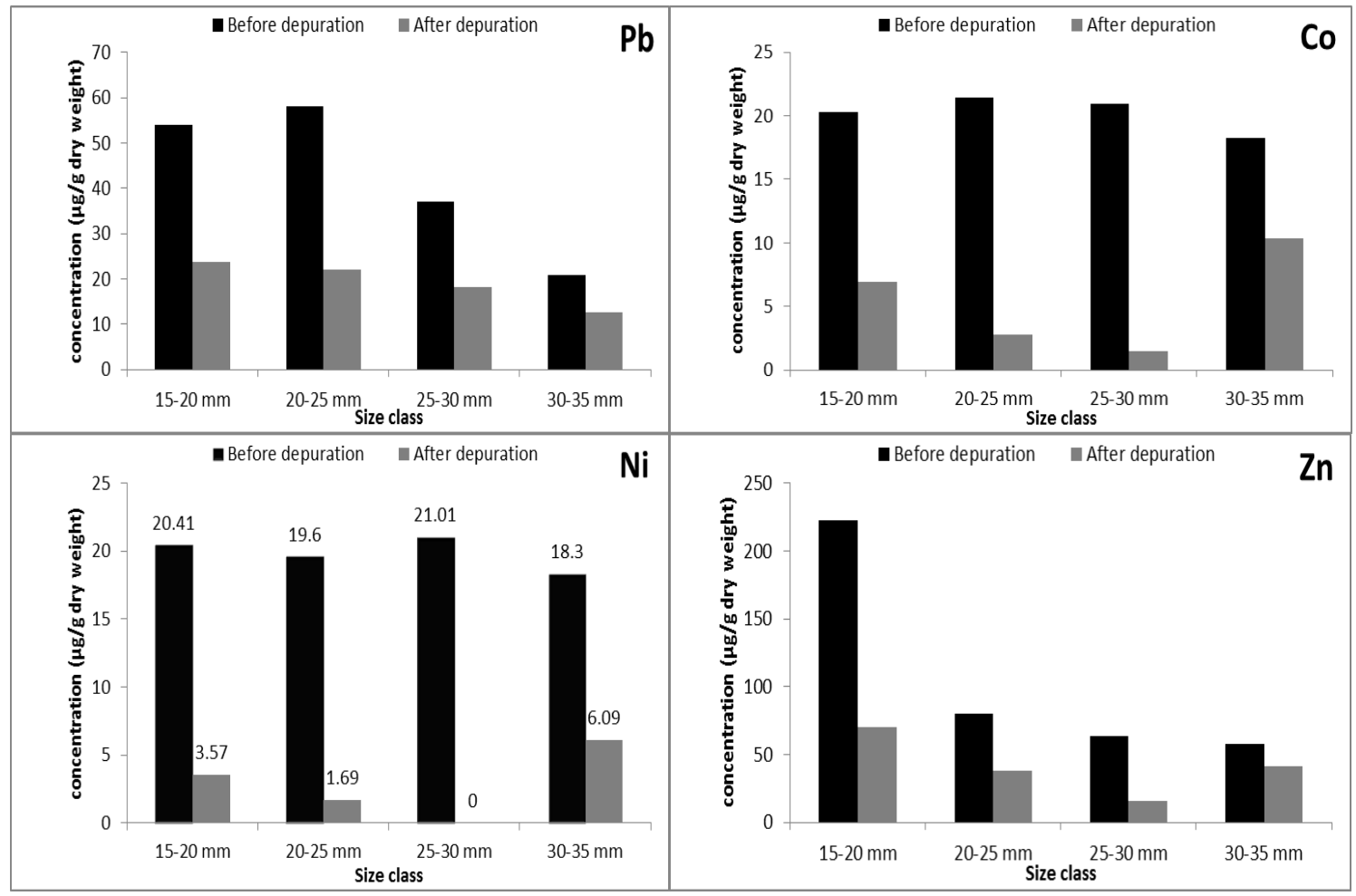

Fig. 4: Mean concentration of heavy metals in different size classes of $R$. decussatus before and after 3 days - depuration.

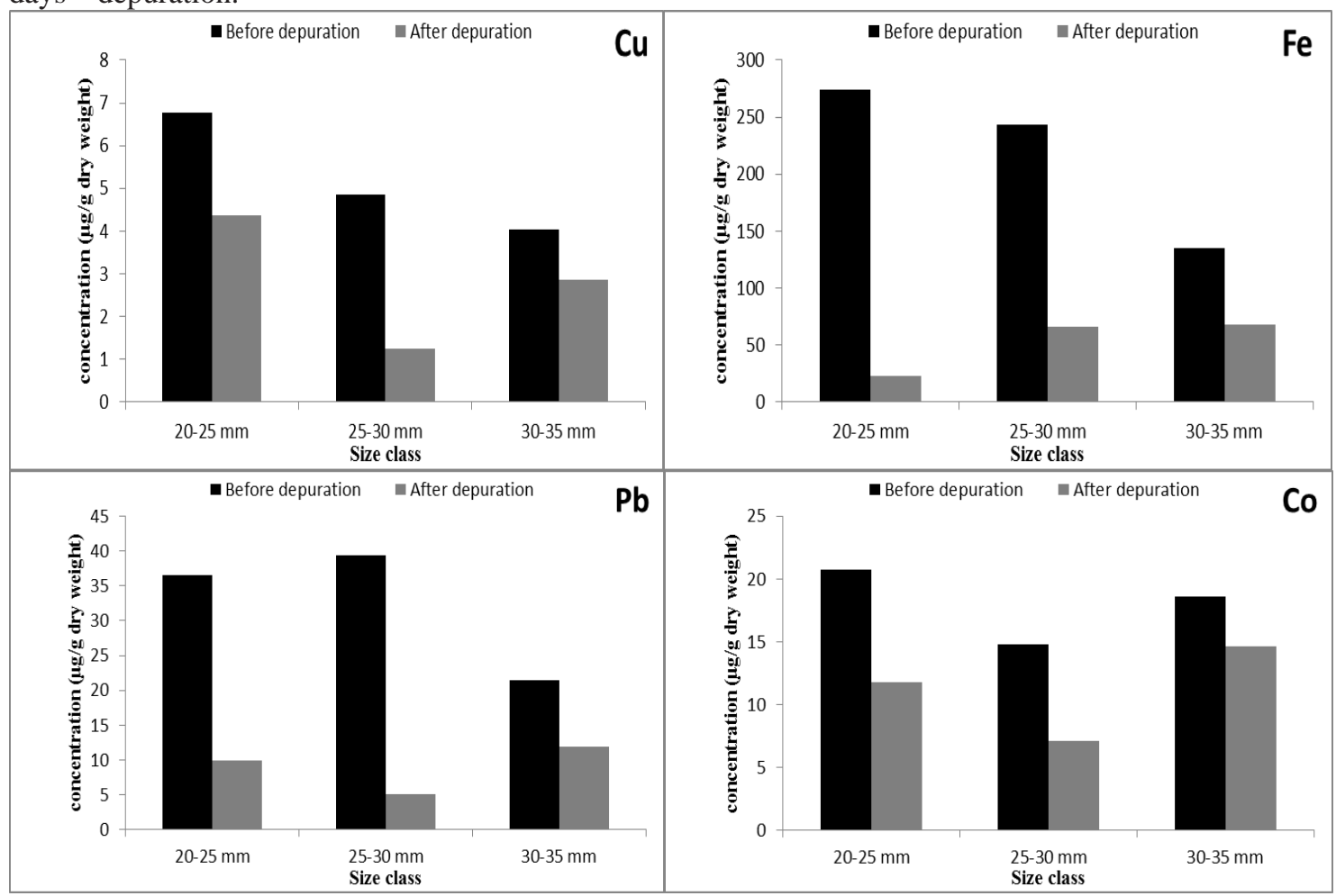




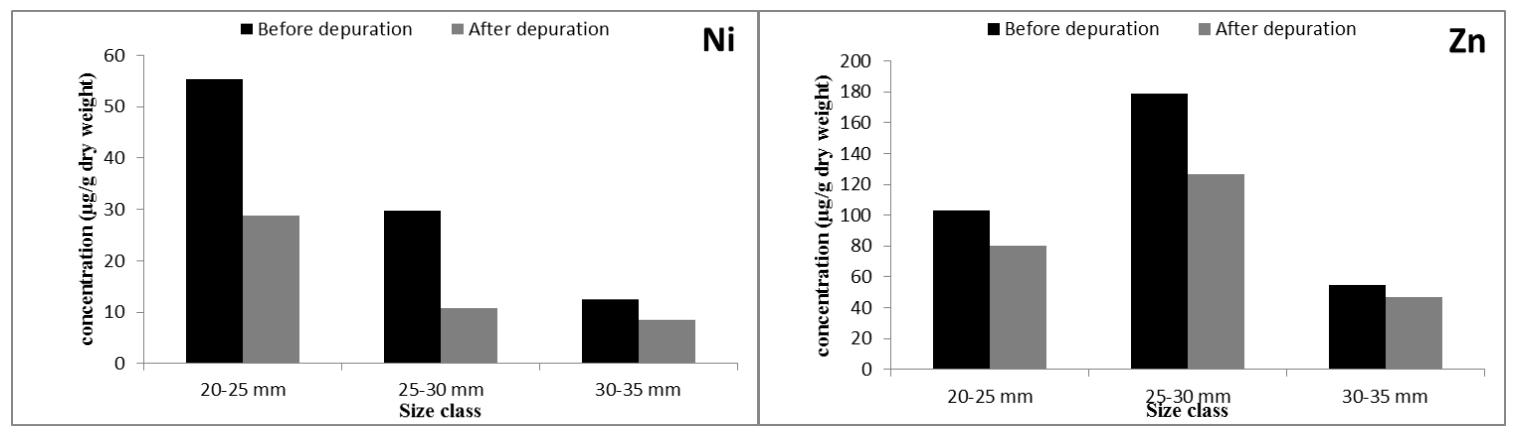

Fig. 5: Mean concentration of heavy metals in different size classes of $P$. undulata before and after 3 days - depuration.

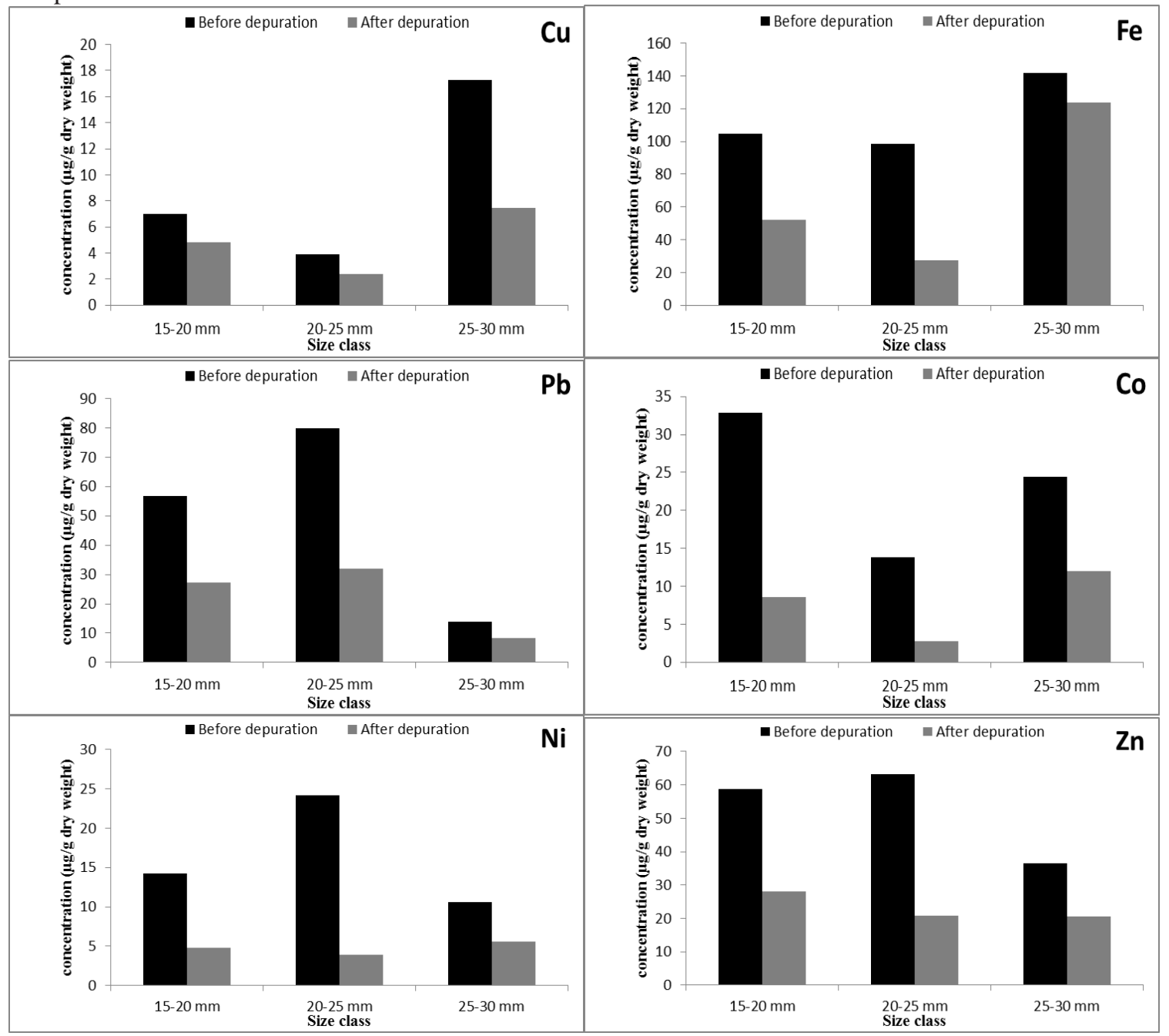

Fig. 6: Mean concentration of heavy metals in different size classes of $V$. Pullastra before and after 3 days - depuration. 
Table 5: Depuration rate $\left(\mu \mathrm{g} / \mathrm{g}\right.$ dry weight $\left.\mathrm{day}^{-1}\right)$ of heavy metals in the soft tissues of studied species through different size classes.

\begin{tabular}{|c|c|c|c|c|c|c|c|c|c|c|}
\hline \multirow{3}{*}{ Metal } & \multicolumn{10}{|c|}{ Depuration rate } \\
\hline & \multicolumn{4}{|c|}{$\boldsymbol{R}$ decussatus } & \multicolumn{3}{|c|}{$V \cdot$ pullastra } & \multicolumn{3}{|c|}{ P. undulata } \\
\hline & $\begin{array}{c}15-20 \\
\mathrm{~mm}\end{array}$ & $\begin{array}{c}20-25 \\
\mathrm{~mm}\end{array}$ & $\begin{array}{c}25-30 \\
\mathrm{~mm}\end{array}$ & $\begin{array}{c}30-35 \\
\mathrm{~mm}\end{array}$ & $\begin{array}{c}15-20 \\
\mathrm{~mm}\end{array}$ & $\begin{array}{c}20-25 \\
\mathrm{~mm}\end{array}$ & $\begin{array}{c}25-30 \\
\mathrm{~mm}\end{array}$ & $\begin{array}{c}20-25 \\
\mathrm{~mm}\end{array}$ & $\begin{array}{c}25-30 \\
\mathrm{~mm}\end{array}$ & $\begin{array}{c}30-35 \\
\mathrm{~mm}\end{array}$ \\
\hline $\mathrm{Cu}$ & 2.88 & 4.26 & 1.00 & 0.50 & 0.73 & 0.51 & 3.27 & 0.80 & 1.20 & 0.39 \\
\hline $\mathrm{Fe}$ & 90.88 & 198.73 & $36.54 \mid$ & 17.66 & 17.43 & 23.70 & 6.04 & 83.55 & 59.27 & 22.37 \\
\hline $\mathrm{Pb}$ & 10.07 & 12.01 & 6.24 & 2.79 & 9.83 & 15.90 & 1.93 & 8.91 & 11.40 & 3.14 \\
\hline $\mathrm{Co}$ & 4.47 & 6.21 & 6.48 & 2.61 & 8.08 & 3.71 & 4.14 & 2.98 & 2.56 & 1.32 \\
\hline $\mathrm{Ni}$ & 5.61 & 5.97 & 7.00 & 4.07 & 3.15 & 6.77 & 1.67 & 8.89 & 6.35 & 1.31 \\
\hline $\mathrm{Zn}$ & 50.77 & 13.83 & 15.82 & 5.44 & 10.26 & 14.09 & 5.28 & 7.69 & 17.47 & 2.64 \\
\hline
\end{tabular}

Table 6: Reduction rate of heavy metals in the soft tissues of studied species through different size classes.

\begin{tabular}{|c|c|c|c|c|c|c|c|c|c|c|}
\hline \multirow{3}{*}{ Metal } & \multicolumn{10}{|c|}{ Metal reduction rate (\%) } \\
\hline & \multicolumn{4}{|c|}{$\boldsymbol{R}$ decussatus } & \multicolumn{3}{|c|}{ V. pullastra } & \multicolumn{3}{|c|}{ P. undulata } \\
\hline & $\begin{array}{c}15-20 \\
\mathrm{~mm}\end{array}$ & $\begin{array}{c}20-25 \\
\mathrm{~mm}\end{array}$ & $\begin{array}{c}25-30 \\
\mathrm{~m} m\end{array}$ & $\begin{array}{c}30-35 \\
\mathrm{~mm}\end{array}$ & $\begin{array}{c}15-20 \\
\mathrm{~mm}\end{array}$ & $\begin{array}{c}20-25 \\
\mathrm{~mm}\end{array}$ & $\begin{array}{c}25-30 \\
\mathrm{~mm}\end{array}$ & $\begin{array}{c}20-25 \\
\mathrm{~mm}\end{array}$ & $\begin{array}{c}25-30 \\
\mathrm{~mm}\end{array}$ & $\begin{array}{c}30-35 \\
\mathrm{~mm}\end{array}$ \\
\hline $\mathrm{Cu}$ & 65.09 & 67.12 & 32.64 & 25.34 & 31.23 & 38.97 & 56.71 & 35.60 & 74.02 & 29.21 \\
\hline $\mathrm{Fe}$ & 83.05 & 93.07 & 62.63 & 56.00 & 50.00 & 72.00 & 12.79 & 91.52 & 73.00 & 49.84 \\
\hline $\mathrm{Pb}$ & 56.00 & 62.03 & 50.61 & 40.00 & 52.09 & 59.77 & 41.30 & 73.01 & 87.00 & 43.98 \\
\hline Co & 65.99 & 87.01 & 92.97 & 42.97 & 73.80 & 80.17 & 50.91 & 43.22 & 51.92 & 21.28 \\
\hline $\mathrm{Ni}$ & 82.51 & 91.38 & 100.00 & 66.72 & 66.39 & 83.99 & 47.21 & 48.11 & 64.01 & 31.57 \\
\hline $\mathrm{Zn}$ & 68.54 & 52.00 & 75.01 & 28.29 & 52.40 & 66.95 & 43.46 & 22.40 & 29.28 & 14.56 \\
\hline
\end{tabular}

Table 7: Pearson correlation coefficient among lengths and depuration rates $(\mu \mathrm{g} / \mathrm{g}$ dry weight day $^{-1}$ ) of heavy metals in the studied species and its significance values.

\begin{tabular}{|c|c|c|}
\hline Species & metals & $\mathrm{r}$ \\
\hline \multirow{6}{*}{$R$ decussatus } & $\mathrm{Cu}$ & $-0.706^{*}$ \\
\hline & $\mathrm{Fe}$ & $-0.624^{*}$ \\
\hline & $\mathrm{Pb}$ & $-0.893^{* \pi}$ \\
\hline & Co & -0.526 \\
\hline & $\mathrm{Ni}$ & -0.397 \\
\hline & $\mathrm{Zn}$ & $-0.842^{* \pi}$ \\
\hline \multirow{6}{*}{ P. undulata } & $\mathrm{Cu}$ & $-0.813^{* 7}$ \\
\hline & $\mathrm{Fe}$ & $-0.949^{* t}$ \\
\hline & $\mathrm{Pb}$ & $-0.775^{*}$ \\
\hline & $\mathrm{Co}$ & -0.339 \\
\hline & $\mathrm{Ni}$ & $-0.991^{* *}$ \\
\hline & $\mathrm{Zn}$ & -0.386 \\
\hline \multirow{6}{*}{$V$-pullastra } & $\mathrm{Cu}$ & $0.733^{*}$ \\
\hline & $\mathrm{Fe}$ & $0.794^{*}$ \\
\hline & $\mathrm{Pb}$ & -0.638 \\
\hline & $\mathrm{Co}$ & -0.437 \\
\hline & $\mathrm{Ni}$ & -0.259 \\
\hline & $\mathrm{Zn}$ & $-0.771^{*}$ \\
\hline
\end{tabular}

Significant level: $*=\mathrm{p}<0.05 ; * *=\mathrm{p}<0.01$ 


\section{DISCUSSION}

During the present study, three species of edible clams were collected from Lake Timsah, Suez Canal, Egypt. This site is exposed to different industrial wastes which may reflect the reason of the high concentration of heavy metals in studied species. This confirms the fact that clams are the most reliable tool for identifying sources of biological available heavy metals (Yap et al., 2009).

There are many factors which influence trace metal accumulation in animals such as salinity and temperature (Phillips, 1976). Other factors influencing bioaccumulation of trace metals include life stage of organisms and mode of feeding (Okazaki and Pamietz, 1981). Factors especially important in decreasing bioaccumulation of heavy metals are low $\mathrm{pH}$, low temperature, and high organic content of the substrate. The temperature and $\mathrm{pH}$ effects might be explained by increased stress at reduced temperature and $\mathrm{pH}$, resulting in reduced food intake and/or diminished mucus secretion in the gills (Elder and Collins, 1991).

The present work showed that $\mathrm{Fe}$ and $\mathrm{Zn}$ were the most abundant metals in the sediments. High $\mathrm{Fe}$ and $\mathrm{Zn}$ concentration is related to its wide distribution in the environment, since most rocks and minerals contain $\mathrm{Zn}$ and natural and anthropogenic activities result in the transport of this metal through the atmosphere, water and soil (Fatoki and Awofolu, 2003). The cuurent results are in agreement with the previous studies (Ibrahim and Abu El-Regal, 2014; AbdEIGhany, 2017; Mohammad et al., 2017). Gabr and Gab-Alla (2008) found that $\mathrm{Zn}$ was the high concentration in Suez Canal while the low concentrations were recorded for Fe. This result disagrees with the present study where the most dominant metal in sediment was Fe. The concentrations of $\mathrm{Cu}, \mathrm{Pb}, \mathrm{Co}$ and $\mathrm{Zn}$ in the present study were less than Gabr and Gab-Alla (2008) results at the same area.

The copper concentration in sediment in the present study were less than its values in the previous study (El- Shenawy et al., 2016; AbdEIGhany, 2017; Mohammad et al., 2017) while its concentration was higher than El-Gamal (2011). The iron concentration was higher than Gabr and Gab-Alla (2008); Ibrahim and Abu El-Regal (2014); AbdEIGhany (2017) results while it was less than El- shenawy et al. (2016); Mohammad et al. (2017). The value of $\mathrm{Pb}$ in sediment was less than its values in the previous studies (Ibrahim and Abu El-Regal, 2014; El- Shenawy et al., 2016; Abdelghany, 2017); Mohammad et al., 2017).

Gabr and Gab-Alla (2008); El Gamal (2011), Ibrahim and Abu El-Regal(2014); ElShenawy et al. (2016) found that the concentration of all heavy metals was high in sediment than water. Their results are agreement with the present results. The high concentration of heavy metals in sediment, revealed that the metals precipitate in sediment than its dissolving in water. The concentration of $\mathrm{Cu}, \mathrm{Fe}$ and $\mathrm{Pb}$ in water were high in the present study than its value in the previous studies (Gabr and Gab-Alla, 2008; Saad El-Din et al., 2014). While their concentration was less than El Khodary et al. (2018); Salama et al. (2020) results. The 
differences of the concentration of heavy metal between the present study and the previous studies may be attributed to different sources of pollution and its amount and different study sites or location..

The permissible limit for heavy metals differs from organization to another and from country to another. $\mathrm{Pb}$ is the second element on the top 20 list of the most poisoning heavy metals. Its target organs are bones, brain, blood, kidneys, thyroid gland, reproductive and cardiovascular systems (Massadeh et al., 2004). By comparing the data of the present study (Table 1) to permissible limits on dry weight basis, it was observed that lead $(\mathrm{Pb})$ concentration (av. 42.49, 32.44 and50.15 $\mu \mathrm{g} / \mathrm{g} \mathrm{d}$.wt.) for $R$. decussatus, $P$. undulata and $\quad V$. pullastra, respectively, exceeded the lowest maximum permissible limits set for molluscs of $1.5 \mu \mathrm{g} / \mathrm{g}$ d.w, prescribed by FDA (2001) and WHO (1989) and other organizations. Similar observations were recorded for iron (Fe) and zinc ( $\mathrm{Zn})$ (Table 8) which exceeded the lowest prescribed permissible limits by WHO (1989) and FAO (1992). High levels of zinc cause pancreatitis, anemia, muscle pain and acute renal failure (Pais and Benton Jones, 1997). The concentration of $\mathrm{Cu}$ and $\mathrm{Ni}$ were less than the lowest prescribed permissible limits (Table 8).

The concentrations of heavy metals differed between the studied species. Szefer $\boldsymbol{e t} \boldsymbol{a l}$. (1999) recorded significant interspecies variation in metals accumulation in the soft tissue of molluscs species collected from the Gulf of Aden, Yemen and this agree with the present study. The concentration of $\mathrm{Cu}, \mathrm{Fe}$ and $\mathrm{Ni}$ were high in $R$. decussatus than $P$. undulata and $V$. pullastra while $\mathrm{Pb}$ and Co recorded high values in $V$. pullastra. Temporal variations in heavy metals accumulation may be attributed to different factors such as food supply for the mollusc populations and/or runoff of particulate metals into the coastal waters and to various environmental (physicochemical conditions of water) and biological factors (physiological state of organism) (Otchere et al., 2003; Sokolowski et al., 2004).

The concentration of studied metals for studied species in the present study were more or less comparable with those recorded in mollusca species by El-Moselhy et al. (1999); El-Moselhy and Gabal (2004); El-Moselhy and Yassien (2005); Kesavan et al. (2013); Sharaf and Shehata (2015). The variation in metals content in the different mollusca species may be attributed to the bioavailability of each species to uptake metals from the surrounding areas (El-Moselhyet al., 2016).

Current results revealed that the highest metal concentrations were Fe and $\mathrm{Zn}$ while the lowest concentrations were $\mathrm{Cu}$ and $\mathrm{Ni}$ in all studied species. This result may be due to the increasing of these metals into the lake. These findings are in agreement with previous observations recorded by Ibrahim and EI-Regal (2014); Sharaf and Shehata (2015); Abd El-Azim et al. (2018) who studied the heavy metals concentrations in Lake Timsah, and found that Fe reached the maximum values in the soft tissues of the studied bivalve species.

On studying the relationship between size and heavy metal concentration, it was observed that the smallest $R$. decussatus, $P$. undulata and $V$. pullastra contained the 
highest levels of heavy metals $(\mathrm{Cu}, \mathrm{Fe}, \mathrm{Pb}, \mathrm{Co}, \mathrm{Ni}$ and $\mathrm{Zn})$. This is in agreement with Cossa et al. (1980); Joiris and Azokwu (1999). Williamson (1980) observed similar results with $\mathrm{Cd}, \mathrm{Pb}$ and $\mathrm{Zn}$ in a population of snails and attributed this pattern and its variations to the metabolic activity of the animals. He suggested that the increase in metabolic rates in younger individuals may affect metal uptake and elimination differentially. Usero et al. (1997) noticed that independence between metal concentrations and size occurs when the uptake and excretion rates of the metals balance.

Balaji and Rao (2000) found negative correlation between concentration of $\mathrm{Cu}, \mathrm{Pb}$ and $\mathrm{Zn}$ and size of Mytilopsis sallei. These results agreed with the present study except $V$. pullastra which had positive correlation between $\mathrm{Cu}$ and Fe concentration with its size. Also Nik et al. (2014) studied the relation between the concentration of heavy metals and the size of different species (Donax cuneatus, Perna viridis, Anadara granosa and Cryptomya elliptica) from Kuala Selangor, Malaysia. He found negative correlation between metal concentration ( $\mathrm{Fe}, \mathrm{Pb}$ and $\mathrm{Zn}$ ) with clam size. This result agrees with the present study for all species except Fe in $V$. pullastra.Yap et al. (2009) suggested that there might be differences in physiology between young and older mussels. Since large and aged mussels tended to pump less water, through their bodies per unit of body weight, the uptake of metals was lower than that in smaller individuals. The surface area to volume ratios decreased with size, and this affected the relative contribution of the adsorbed metal content to the total body burden of heavy metals (Swaileh and Adelung, 1994; Cossa et al., 1997).

EL-Moselhy and Yassien (2005) studied the relationships between size of the two bivalve species and the concentration of heavy metals. They recorded that all metals have negative correlations with shell-length in studied species ( $P$. undulata and $G$. pectinatum). These results agreed with the present study. These inverse relationships can be attributed to different reasons: 1) variation in the uptake and excretion rates of metals between small and large animals, 2) small animals have ability to eat more than the larger one which lead to accumulate pollutant in its body, 3) dilution of the pollutant in the tissues of the large animals. In general, it can be stated that, large individuals of the studied bivalve species in the present study are able to regulate the metals content in their tissues.

AbdEIGhany (2017) studied the relationships between size of Venerupis decussata and the concentration of heavy metals $(\mathrm{Cu}, \mathrm{Fe}, \mathrm{Pb}, \mathrm{Co}, \mathrm{Zn}$ and $\mathrm{Cd})$. He recorded that, all metals have negative correlations with shell size in study species. These results agreed with the present study. Ibrahim and El-Regal (2014) studied the relationships between shell length of two species (Venerupis aurea and Thais carnifira) and the concentration of heavy metals $(\mathrm{Cu}, \mathrm{Fe}, \mathrm{Pb}, \mathrm{Mn}, \mathrm{Zn}$ and $\mathrm{Cr})$. They reported that there is negative correlation with $V$. aurea and positive correlation with Thais carnifira.

The accumulation and depuration kinetics is dependent on several factors, namely the type of contaminant, the sources of contamination (e.g., sediment, water, food), the conditions of exposure (i.e., controlled versus field), the bioavailability of the contaminant, etc (Cardoso et al., 2015). Unfortunately, little information on this topic is available in the literature, especially concerning the effect of different parameters on 
depuration rate of the commercial clams; however the present study is one of the few works that can surpass this knowledge gap.

Several trials make depuration by transplanting the clams or oysters in another clean field (Saed et al., 2004; Gabr and Gab-Alla, 2008). But these trials needed long periods for depuration that ranged from 50 days to 6 months. Other studies under took depuration in different experimental conditions (EL-Shenawy, 2004; Saed et al., 2004; El-Gamal, 2011). They found that it needs $2-32$ days for complete depuration. These results referred that experimental depuration were faster for reducing the metal contents in bivalves. The present study suggests that depurating edible clams before their use for a period of three days is quite reasonable. This could be achieved in markets before being sold to avoid human toxicity with different pathogenic bacteria and heavy metals.

Previous studies reported higher and lower $\mathrm{Cu}, \mathrm{Fe}, \mathrm{Pb}, \mathrm{Co}, \mathrm{Ni}$ and $\mathrm{Zn}$ reductions in other bivalve species (Paphia undulata, Ruditapes decussatus, Crassostrea gigas and Mytilus smarangdium) subjected to depuration compared to the present study (GnassiaBarelli et al., 1995; El- Shenawy, 2004; El-Gamal, 2011). These results clearly indicate that the pattern and efficiency of depuration rates of toxic and macro/trace elements are influenced by species, time of depuration, element, and initial elemental levels in bivalves and concentration of elements in the water of the depuration facility.

The obtained results from the present study suggest that small individuals of the studied species are faster in elimination of all heavy metals than the largest ones. This idea is similar with bioaccumulation of heavy metals with different clams size where the previous studies revealed that there are negative correlation between metal concentration and clam size (Moselehy and Yassien, 2005; Ibrahim and Abu El-Regal, 2014).

Table 8: The permissible limits for heavy metals set by different organizations.

\begin{tabular}{|c|c|c|c|c|c|c|c|}
\hline Reference & $\mathrm{Cu}$ & $\mathrm{Fe}$ & $\mathbf{P b}$ & $\mathrm{Co}_{0}$ & $\mathrm{Ni}$ & $\mathbf{Z n}$ & unit \\
\hline FAO (1983) & 30 & & 0.5 & & & 40 & $\mu \mathrm{g} / \mathrm{g}$ \\
\hline FAO(1992) & & 100 & $0.5-5$ & & & $30-100$ & $\mu \mathrm{g} / \mathrm{g}$ \\
\hline EC (2001) & & & 1 & & & & $\mu \mathrm{g} / \mathrm{g}$ \\
\hline WHO(1982) & 10 & & 5 & & & 100 & $\mu \mathrm{g} / \mathrm{g}$ \\
\hline WHO(1983) & 30 & & & & & & $\mu \mathrm{g} / \mathrm{g}$ \\
\hline WHO(1989) & 30 & 100 & 2 & & $0.5-1$ & 100 & $\mu \mathrm{g} / \mathrm{g}$ \\
\hline FAO/WHO (1989) & 30 & 100 & & & $40-100$ & 567 & $\mu \mathrm{g} / \mathrm{g}$ \\
\hline USFDA (1990) & & & 11.5 & & & & $\mu \mathrm{g} / \mathrm{g}$ \\
\hline USFDA (1993) & & & & & $70-80$ & & $\mu \mathrm{g} / \mathrm{g}$ \\
\hline FDA (2001) & 100 & & 1.5 & & 80 & 150 & $\mu \mathrm{g} / \mathrm{g}$ \\
\hline $\begin{array}{c}\text { Malaysian Food } \\
\text { Regulation (MFR) } \\
(1985)\end{array}$ & 30 & & 2 & & & 100 & $\mu \mathrm{g} / \mathrm{g}$ \\
\hline
\end{tabular}

\section{REFERENCES}

Abd El-Azim, H. A.; Belal, A. A.; El-Salam, E. T. A.; Mourad, F. A. and Elwafa, S. Y. A. (2018). Water pollution by heavy metals in the western lagoon and its effect on Timsah Lake and consequently on Suez Canal. Intl. J. of Env. Sci., 17 (1): 71 - 76. 
Abd-ElGhany, S. R. (2017). Heavy metal bioaccumulation in the edible bivalve Venerupis decussata collected from Port Said, Egypt. Wufenia J., 24 (5): 48 - 62.

Almeida, C. and Soares, F. (2012). Microbiological monitoring of bivalves from the Ria Formosa Lagoon (south coast of Portugal): 20 years of sanitary survey. Mar. Pollut. Bull., 64: 252 - 262.

Anacleto, P. S. L. (2014). Clams from Tagus estuary: microbiological, physiological and chemical responses to depuration, transport and environmental stress (Doctoral dissertation, Universidade de Lisboa (Portugal). 212pp.

APHA (1992). Standard Methods for the examination of water and wastewaters. 16 th ed., (Washington, DC; American Public Health Association). 40pp

Balaji, M. and Rao, K. S. (2000). Size dependent bioaccumulation of heavy metals by Mytilopsis sallei (Recluz) at Visakhapatnam harbor. Indian J. of Exp. Biol., 38: 405 407.

Barile, N. B.; Scopa, M.; Nerone, E.; Mascilongo, G.; Recchi, S.; Cappabianca, S. and Antonetti, L., (2009). Study of the efficacy of closed cycle depuration system on bivalve molluscs. Vet. Ital. 45 (4): 555 - 566.

Benavides, M. P.; Gallego, S. M. and Tomaro, M. L. (2005). Cadmium toxicity in plants. Braz. J. Plant. Physiol. 17: 21 - 34.

Cardoso, P. G.; Grilo, T. F.; Reis, A. T.; Coelho, J. P.; Pereira, E. and Pardal, M. A. (2015). Field transplantation of the bivalve Scrobicularia plana along a mercury gradient in Ria de Aveiro (Portugal): Uptake and depuration kinetics. Scie. of the Total Env., 512: $55-61$.

Chalek, M. R. (2013). The Time Has Come to Talk of Many Things: Legal Impediments to the Future of Shellfish Relay in Rhode Island. Sea Grant L. \& Pol'y. J., 6: 102pp.

Chevereuil, M.; Blanchard, M.; Teil, M. J.; Carru, A. M.; Testard, P., and Chesterikoff, A. (1996). Evaluation of the pollution by organochlorine compound (polychlorobiphenyles and pesticides) and metals $(\mathrm{Cd}, \mathrm{Cr}, \mathrm{Cu}$ and $\mathrm{Pb})$ in the water and in the zebra mussel (Dreissena polymorpha pallas) of the river Seine. Water, Air, \& Soil Pollut., 88: 371 - 381.

Cossa, D.; Bourget, E.; Pouliot, D.; Piuze, J. and Chanut, J.P. (1980). Geographical and seasonal variations in the relationship between trace metal content and body weight in Mytilus edulis. Mar. Biol., 58: 7 - 14.

Cossa, D.; Martin, J. M.; Takayanagi, K. and Sanjuan, J. (1997). The distribution and cycling of mercury species in the western Mediterranean. Deep Sea Research Part II: Top. Stu. in Oceanogr., 44 (3 - 4): 721 - 740.

Cozzi, L.; Suffredini, E.; Ciccaglioni, G. and Croci, L. (2009). Depuration treatment of mussels experimentally contaminated with $V$. parahaemolyticus and $V$. vulnificus. In: Proceeding ICMSS09, Nantes, France. 6pp.

EC (2001). Commission Regulation (EC) No. 466/2001 Off. J. of Eur. Comm. 1.77/1.

El Khodary, G. M.; Radwan, E. H.; El Ghazaly, M. M. and El Bahnasawy, D. (2018). Marine pollution by some heavy metals and physiological response of Ruditapes decussatus. J. of Biol. \& Appl. Res., 4 (3): 199-217.

El Nemr, A. (2012). Environmental Pollution and its Relation to Climate Change. Nov. Sci. Pub. Inc., 692 pp. 
Elder, J. F. and Collins, J. J. (1991). Freshwater molluscs as indicators of bioavailability and toxicity of metals in surface-water systems. In Reviews of Env.Cont. \& Toxicol., 37 - 79 pp.

El-Gamal, M. M. (2011). The effect of depuration on heavy metals, petroleum hydrocarbons, and microbial contamination levels in Paphia undulata (Bivalvia: Veneridae). Czech J. of Anim. Sci., 56 (8): 345 - 354.

El-Moselhy, Kh. M.; Diab A. A.; Tolba, M. R. and Mohamadein, L. I. (1999). Levels of some heavymetals in coastal water, sediment and the limpet Patella sp. from the northern part of the Gulf of Suez (Suez Bay), Egypt. J. Aquat. Biol. \& Fish., 3 (2): 69 84.

El-Moselhy, K. M.; Saad, E. M.; El-Shaarway, R. F.; Mohamadein, L. I. and Mahmoud, S. A. (2016). Assessment of heavy metals pollution using sediments and bivalve Brachidontes variabilis as bioindicator in the Gulf of Suez, Egypt. Intl. J. of Mar. Sci., 6 (26): 1 - 13.

El-Moselhy, Kh. and Yassien, M. H. (2005). Accumulation patterns of heavy metals in two venus clams, Paphia undulata (Born, 1780) and Gafrarium pectinatum (Linnaeus, 1758), from Lake Timsah. Suez Canal, Egypt. Egyp. J.of Aquat. Res., 31(1): 13 - 29.

El-Moselhy, Kh. M. and Gabal, M. N. (2004). Trace metals in water, sediments and marine organisms from the northern part of the Gulf of Suez, Red Sea, J. Mar. Sys., 46: $39-46$.

El-Shenawy, N. S. (2004). Heavy-metal and microbial depuration of the clam Ruditapes decussatus and its effect on bivalve behavior and physiology. Env. Toxicol., 19: 143 153.

FAO (1983). Compilation of legal limits for hazardous substances in fish and fishery products. FAO Fish Circular. 464: 5-100.

FAO (1992). Committee for inland fisheries of Africa: Report of the third session of the working party on pollution and fisheries. FAO Fish. Rep., 471: 43 pp.

FAO/WHO (1989). National Research Council Recommended Dietary Allowances (10th ed). National Academy Press, Washington, DC. USA. 302pp.

Fatoki, O. S. and Awofolu, R. (2003). Levels of Cd, Hg and $\mathrm{Zn}$ in some surface waters from the Eastern Cape Province, South Africa. Water, 29: 375 - 380.

FDA (2001). Fish and Fisheries Products Hazards and Controls Guidance, third ed. Center for Food Safety and Applied Nutrition, US Food and Drug Administration. 498pp Fernandez-Tajes, J.; Fl_orez, F.; Pereira, S.; R_abade, T.; Laffon, B. and M_endez, J. (2011). Use of three bivalve species for biomonitoring a polluted estuarine environment. Env. Mon. \& Ass., 177: 289 -300.

Gabr, H. R. and Gab-Alla, A. A. F. (2008). Effect of transplantation on heavy metal concentrations in commercial clams of Lake Timsah, Suez Canal. Egypt. Oceanol., 50 (1): 83-93.

Gnassia-Barelli, M.; Rom_eo, M. and Puiseux-Daob, S. (1995). Effects of cadmium and copper contamination on calcium content of the bivalve Ruditapes decussatus. Mar. Env. Res., 39 (1-4), 325 - 328.

Ibrahim, N. K. and Abu El-Regal, M. (2014). Heavy metals accumulation in marine edible molluscs, Timsah Lake, Suez Canal, Egypt. ARPN J. of Sci. \& Technol.- Intl., 4 (4): 282 - 288. 
Joiris, C. R. and Azokwu, M. I. (1999). Heavy Metals in the Bivalve Anadara (Senilia) senilis from Nigeria. Mar. Pollut. Bull. 38 (7): 618 - 622.

Jones, S. H.; Howell, T. L. and O'Neill, K. R. (1991). Differential elimination of indicator bacteria and pathogenic Vibrio spp. from eastern oysters (Crassostrea virginica Gmelin, 1971) in a commercial controlled purification facility in Mar. J. of Shell. Res., 10 (1): $105-112$.

Kesavan, K.; Murugan, A.; Venkatesan, V. and Vijay Kumar, B. S. (2013). Heavy metal accumulation in molluscs and sediment from Uppanar estuary, southeast coast of India,Thalassas. Intl. J. of Mar. Sci., 29 (2): 15 - 21.

Laffon, B.; R_abade, T.; P_asaro, E. and M_endez, J. (2006). Monitoring of the impact of Prestige oil spill on Mytilus galloprovincialis from Galician coast. Env. Intl., 32: 342 - 348 .

Malaysian Food and Regulations (1985). In Hamid Ibrahim, Nasser and Yap Thiam Huat. Malaysian Law on Food and Drugs. Kuala Lumpur, Malaysia Law Publisher.

Marwa, I. S. El-Din and El-HaK, H. N. G. (2017). Impact of heavy metals contamination on spring abundance of aquatic macro-invertebrates inhabiting Lake Timsah. Egypt. J. Water Sec. (3): 2345 - 0363.

Massadeh, A., Tahat, M., Jaradat, Q. and Al-Momani, L. (2004). Lead and cadmium contamination in roadside soils in Irbid city, Jordan: a case study. J. of Soil Cont., 13 (4): $347-359$.

Mohammad, S.; Ibrahim, R. and Mohamed, S. (2017). Heavy metals and some nutritional elements in the Mediterranean carpet shell clam Donax semistriatus. Indian. J. of Geo-Mar. Sci., 46 (6): 1145 - 1154.

Muhammad, S.; Shah, M.T. and Khan, S. (2011). Health risk assessment of heavy metals and their source apportionment in drinking water of Kohistan region, northern Pakistan. Microchem. J., 98: 334 - 343.

Nik, A.; Sabarina, M. Y.; Noor, A.; Nasir, N. M.; Nurul, A.; Wan, N. and Zanariah, I. (2014). Assessment of heavy metal accumulation in selected bivalve species from Kuala Selangor, Malaysia. Env. Biol., 8 (18): 8 -14.

Nordberg, G. F. (2010). Biomarkers of exposure, effects and susceptibility in humans and their applic ation in studies of interactions among metals in China. Toxicol. Lett. 192 (1): 45 - 49 .

Okazaki, R. K. and Panietz, M. H. (1981). Depuration of twelve trace metals in tissues of oysters, Crassostrea gigas and Crassostrea virginica. Mar. Biol., 63: 113 - 120.

Oregioni, B. and Astone, S. (1984). The determination of selected trace metals in marine sediments by flameless/ flame- atomic absorption spectrophotometry IAEA Monaco Laboratory, Internal Report. J. of Env. Protec., 8 (1): 38pp.

Otchere F. A.; Joiris C. and Holsbeek L. (2003). Mercury in the bivalves Anadara (Senilis) senilis, Perna perna and Crassostrea tulipa from Ghana, Sci. Total Env., 304: 369 - 375.

Pais, I. and Benton Jones, Jr. J. (1997). The Handbook of Trace Elements. Saint Lucie Press, Boca Raton, Florida, 223 pp.

Pellerin, J. and Amiard, J. C. (2009). Comparison of bioaccumulation of metals and induction of metallothioneins in two marine bivalves (Mytilus edulis and Mya arenaria). Comparative Biochemistry and Physiology Part C: Toxicol. \& Pharmacol., 150 (2): 186 -195. 
Phillips, D. J. H. (1976). The common mussel Mytilus edulis as an indicator of pollution by zinc, cadmium, lead and copper. I. Effects of environmental variables on uptake of metals. Mar. Biol., 38 (1): 59 - 69.

Richards, G. P. (1988). Microbial purification of shellfish: a review of depuration and relaying. J. of Food Prot., 51(3): 218 - 251.

Saad El-Din, M. I.; Sakiko, Y.; Mohamed, S. Z.; Bedir, M. A. and Nishimura, O. (2014). Investigating the use of Sphaeroma serratum (Crustacea, Isopoda) as bioindicator for heavy metals pollution in Lake Timsah, Suez Canal using alkaline comet assay technique. Egypt. Acad. J. of Bio. Sci., B. Zool., 6 (1): 7 - 26.

Saed, K.; Ismail, A.; Omar, H. and Kusnan, M. (2004). Heavy metal depuration in flat tree oysters Isognomon alatus under field and laboratory conditions.Tox. \& Env. Chem., 86 (3): 171 - 179.

Salama, W. M.; Mona, M. H. and Ghoneium, A. Z. (2020). Health status of data mussel "Lithophaga lithophaga, family Mytilidae" in Alexanderia, Egypt:potential effects of the heavy metal pollution. Egypt. J. of Zool.,73: 26 - 38.

Sharaf, H. M. and Shehata, A. M., (2015). Heavy metals and hydro-carbon concentrations in water, sediments and tissue of Cyclope neritea from two sites in Suez Canal, Egypt and histopathological effects. J. Env. Health Sci. Eng., 13: 14-21.

Sokolowski, A.; Bawazir, A. S. and Wolowicz, M. (2004). Trace metals in the brown mussel Perna pernafrom the coastal waters off Yemen (Gulf of Aden): How concentrations are affected by weight, sex, and seasonal cycle, Arch. Env. Cont. \& Toxicol., 46: 67 - 80.

Stankovic, S. and Jovic, M. (2012). Health risks of heavy metals in the mediterranean mussels as seafood. Env. Chem., 10 (2): 119 - 130.

Swaileh, K. M. and Adelung, D. (1994). Levels of trace metals and effect of body size on metal content and concentration in Arctica islandica L. (Mollusca: Bivalvia) from Kiel Bay, Western Baltic. Mar. pollut. Bull., 28 (8): 500 - 505.

Szefer, P.; Ali, A. A.; Ba-Haroon, A. A.; Rajeh, A. A.; Geldon, J. and Nabrzyski, M. (1999). Distribution and relationships of selected trace metals in molluscs and associated sediments from the Gulf of Aden, Yemen. Env. Pollut.,106: 299 - 314.

UNEP/FAO/IAEA (1982). Determination of total Cadmium, Zinc, Lead and Copper in selected marine organisms by Atomic Absorption Spectrometry. Reference methods for marine pollution studies No.11. United Nations Environmental Programme. Geneva, $21 \mathrm{pp}$

Usero, J.; Gonzales-Regalado, E. and Gracia, I. (1997). Trace metals in bivalve mollusks Ruditapes decussates and Ruditapes philippinarum from the Atlantic coast of southern Spain. Env. Intl., 23: 291 - 298.

Usero, J.; Morillo, J. and Gracia, I. (2005). Heavy metal concentration in mollusks from the Atlantic coast of southern Spain. Chemo., 59: 1175 - 1181.

USFDA (1990). National Shellfish Sanitation Program Guide for the Control of Molluscan Shellfish 2007. Washington, 489pp.

USFDA (1993). Guidance Document for Cadmium in Shellfish. US Department of Health and Human Services, Public Health Service, Washington, 44pp.

Wahi, A. R.; Vun L. W. and Mohd Harun, A. (2009). Accumulation and depuration of heavy metals in the hard clam (Meretrix meretrix) under laboratory conditions. Trop. Life Sci. Res., 20: 17 - 24. 
Waykar, B. and Deshmukh, G. (2012). Evaluation of bivalves as bioindicators of metal pollution in freshwater. Bull. of Env. Cont. \& Toxicol., 88: 48 - 53.

WHO (1982). Toxicological evaluation of certain food additives, WHO Food Addit. Ser. No 17, World Health Org., Geneva, 28 - 35.

WHO (1989). Heavy metals environmental aspects. World Health Organization, Environment Health Criteria, 85 pp.

Williamson, P. D. (1980). Variables affecting body burdens of lead, zinc and cadmium in roadside populations of the snail Cepaeahortensis. Oceanologia., 44: 213 - 220.

Yap, C. K.; Kamarul, A. R.; and Edward, F. B. (2009). Heavy metal concentrations $(\mathrm{Cd}, \mathrm{Cu}, \mathrm{Ni}, \mathrm{Pb}, \mathrm{Fe}$ and $\mathrm{Zn})$ in different soft tissues and shells of Pholas orientalis collected from Sekinchan and Pantai Remis, Selangor. Malaysian. Appl. Biol. J., 38 (1): $21-27$.

Yap, C. K.; Ismail, A.; Omar, H. and Tan, S. G. (2003). Accumulation, depuration and distribution of cadmium and $\mathrm{Zn}$ in the green-lipped mussel Perna viridis (Linnaeus) under laboratory conditions. Hydrobiologia., 498: 151 - 160.

Zhao, L.; Yang, F.; Yan, X.; Huo, Z., and Zhang, G. (2012). Heavy metal concentrations in surface sediments and manila clams (Ruditapes philippinarum) from the Dalian coast, China after the Dalian Port oil spill. Biol. Trace Elem. Res., 149: 241 247.

Zuykov, M.; Pelletier, E. and Harper, D. A. T. (2013). Bivalve mollusks in metal pollution studies: from bioaccumulation to biomonitoring. Chemo., 93: 201-208. 